\title{
What Is It Like To Be a Bat in the Time of Covid-19, or How Many Pandemics Could We Have?
}

\section{—_ Goran Đurđević, Suzana Marjanić}

V zadnjih dveh letih (2020-2021) je ves svet prizadela pandemija Covid-19, zaradi česar so se pojavile različne domneve, alternativna dejstva in lažne novice. Med temi so najbolj prevladovale novice o netopirjih kot krivcih za širjenje virusa in posredno o kitajski prehrani kot glavnem vzroku. Vendar ni dokazov, da te povezave $\mathrm{v}$ trikotniku netopir-virus-človek veljajo, vir okužbe pa ni bil ugotovljen. Poleg netopirjev so ti virusi prisotni tudi pri drugih živalih, kot so kamele, luskavci in ljudje. Zato posamezni znanstveniki obračajo situacijo tako, da predstavljajo možnost prenosa virusa z ljudi na živali. Kljub temu pa je postalo demoniziranje netopirjev »sprejemljivo«. V zvezi s tem nas različni avtorji opozarjajo na določene zgodovinske kontekste pojmovanja in dojemanja netopirjev ter na podobnosti in razlike teh pojmovanj $\mathrm{v}$ času pandemije, pri čemer se nanje sklicujejo predvsem $\mathrm{v}$ kontekstu Hrvaške in sveta. Na koncu članek prikaže zgodbe o netopirjih kot pokazatelja reprezentacij Drugosti ter krepitve binarne in hierarhične delitve na »nas« in »njih«.

KLJUČNE BESEDE: koronavirusna pandemija, netopir, sinofobija, (kritične) študije živali, primerjalna mitologija, popularna kultura
In these paired years (2020-2021), the whole world has been impacted by the Covid-19 pandemic, which has resulted in the emergence of different presumptions, alternative facts, and fake news. Among those, the most dominant news was about bats as the culprits of expansion of the virus and, indirectly, the Chinese diet as the root cause. However, there is no proof that the links in the triangle of bat-virus-human are valid; and the source of infection has not been identified. In addition to bats, these viruses can be found in other animals, such as camels, pangolins, and humans. Therefore, individual scientists are reversing the situation by presenting the possibility of transmitting the virus from humans to animals. Nevertheless, it has become ultimately 'acceptable' to demonise the bat. In this respect, various authors remind us of certain historical contexts of notions and perceptions of the bats, as well as the similarities and differences of those perceptions during the pandemic, referring to it mainly in the context of Croatia and the world. In the end, the article's conclusion is that the story about the bats is, actually, a great indicator of the representations of Otherness and the strengthening of a binary and hierarchical division of 'us' and 'them'.

KEYWORDS: coronavirus pandemic, bat, sinophobia, (critical) animal studies, comparative mythology, popular culture 
Bats are considered even today one of the most victimised and least studied animals. ${ }^{1}$

\title{
THE BAT IN THE POPULAR CULTURE AND THE MYTHOLOGY BEFORE COVID-19
}

Bats $^{2}$ are only flying mammals. Their Latin name is Chiroptera, which comes from ancient Greek $\chi \varepsilon i \rho+\pi \tau \varepsilon \rho o ́ v$ and means 'hand wings'.

Physically, they are small hairy animals with patagium, a large mouth, strong jaws, and claws. These nocturnal animals live in colonies, rest by roosting (hanging upside-down, using their wings), spend winters in hibernation; most of them communicate by echolocation. There are currently more than 1300 species of bats generally divided into small and large bats. Around 30 of those species live in Europe (Hrvatska agencija za okoliš i prirodu 2020). Their diet consists of fruits, mammal's blood (mostly cattle's), ${ }^{3}$ and insects (most of the bat species are preying on insects) (Hrvatska enciklopedija 2020).

\begin{abstract}
Bats are a significant part of the world's ecosystems - they are an important segment in the natural renewal of the tropical forests, in the pollination of a series of night-blooming plants, in the control of the number of nocturnal insects, and that makes them the indicator of the environmental health. They are one of the most persecuted and least studied animal species. (Hrvatska agencija za okoliš i prirodu 2020).
\end{abstract}

Bats are essential partakers of different mythologies, among which Asian, Pacific, and Central American mythology should be highlighted. When it comes to the first-mentioned - Asian myths within Chinese mythology - bats were associated with longevity and luck since the Han dynasty. The connection remained in the Chinese tradition in the later dynasties, so the bats' artistic depictions can be found in different works of art, such as vases, where they are represented together with other motifs, including plants, animals, and clouds. Along with symbolic similarities between the bats and the blessings, particular interpretations associate bats with a less known, almost mythological world in which their sudden appearances are seen as luck or prosperity which comes out of nowhere (Kunz 1984: 394; Voon 2017).

In Japanese mythology, bats are highlighted as positive tropes transferred from China and they represented luck. Bats have been represented on various artefacts (Osaka 2020). Hindu mythology recognises bats in a positive light, as they have served as iconographies

\footnotetext{
1 https://fws.gov/midwest/news/ImportanceOfBats.html

2 Important notices and ideas for bats in mythology and popular culture have been given by Dr Zlatko Bukač from Zadar, Dr Emiliano Gallaga from Mexico City, Robert Kresina from Požega, Jana Krpina from Beijing, and Dr Jelena Kupsjak from Zadar. The English version have been proofread by Adriana Nelson from Cleveland. We are grateful for their contributions.

3 These examples are located in South America and just a few species from 1300 species have been observed consuming cattle's blood.
} 
in various locations and time frameworks. In contemporary times, bats were called 'Indian flying foxes', or fruit-eating bats have been sacred animals in some parts of India, such as Tamil Nadu. They are protected from by because, according to superstitions, these animals are related to the local deity Muniyandi, who was an anthropomorphic representation of a tree. This god will punish anyone who hurt bats. Therefore, local people do not disturb or relocate bats; instead, they protect them. Punishments are often related to personal and financial loss or death. After these penalties, a social ritual with fruits such as banana, coconut and sweet rice has been established to recover and receive forgiveness (Amirthalingam 2005: 130).

Furthermore, bats' role is also positive in the Pacific mythology, where they are linked with Samoan princess married in Tonga, and later with goddess Leutogi. As a part of a peace treaty between the two islands, the princess came to Tonga to save a baby bat. The princess was soon accused of witchcraft and burned. However, bats saved her by urinating on the fire where she was then transferred to an isolated and uninhabited island. Bats further assisted her by bringing her food and keeping her company, which made the uninhabited island populated and suitable for life so that Leutogi would become the goddess of the bats and fertility (Barnes, Hunt 2005: 237 and 259; Leutogi 2020; Mageo 2002: 493-520).

Other positive views of bats derive from the Nandi and Lugen communities from northern and western parts of Kenya, where these mammals are lucky signs and brought fortune, reproduction and long life (Bats 2020). Bats have been referenced in Native American mythology. Specifically, in the religious system of Navajo indigenous communities, the bat is related to the night as a messenger of Talking God, while Big Fly has a similar purpose in the daylight. Bats have represented free will and are positive beings acting as guardians of the sky located in the east (Renfro 2020).

Folktales from South America in the pre-Columbian era have depicted bats as positive creatures. According to a tale from the Gran Chaco part of Argentina, the first hero was both bat and human. He shared his in-depth knowledge with the people to improve their lives. A similar depiction of bats as human helpers can be seen in the tradition of Ge in Brazil, where bats lead lost tribes in seeking light (Benson 2020; Benson 1987: 165-190).

In contrast, in Central American Maya mythology, the bat has a vital role in the world of the dead, and that is highlighted by the very name of Camazotz coming from kame, meaning 'death', and sotz, carrying the meaning 'bat'. According to Popol Vuh, the sacred text narrating the mythology of the Kiche people - one of Maya peoples, the twins and heroes Hunahpu and Xbalanque come across bat-like creatures in the Bat House while they are on their way to the Underworld. They are hiding in the empty gun barrel, but Hunahpu peeks for a moment in order to see if the Sun has risen and pays the price for that: gods, and the bat-like creatures Camazotzes use his head as a ball for the ballgame they are playing (Laird 2018: 76-77; Miller, Taube 1997: 44; Read and Gonzalez 2000: 133; Camazotz 2020).

It seems strange for bats to be related to the negative parts of life mostly representing death in Mesoamerican cultures. In her analysis of bats, Laird wrote an exciting quote for these issues: 
[...] the Maya and other Meso-American cultures had more reason to fear or at least respect bats. These are the regions where not only vampire bats are found, but the largest bat of the Americas, the spectral bat, a carnivore which snatches sleeping birds and rodents by night, dragging them back to its lair full of bones, feathers and other remains (Laird 2018: 77). ${ }^{4}$

In Greco-Roman culture, bats are represented as dual animals - mice and birds, or as creatures that avoid the light. The duality of the bats is presented in Plato's Republic in the parable about a man that is not a man, a stone that is not a stone, a tree that is not a tree, and a bird that is not a bird. The latter is interpreted as an inscription about the bat (Bats, 2020; Plat. Rep. 5.479). Aesop wrote a fable about a bat and a weasel, in which the bat is falling, and the weasel that wants to eat him as a bird catches him. The bat says that it is a mouse, and the weasel lets him go. Soon after, a similar situation occurs: another weasel wants to eat him as a bird, but the bat again successfully avoids its fate by claiming to be a mouse (Bats, 2020; Aesop 2007: 26). Another of Aesop's fable discusses the bat's duality between the mouse and the bird; at first, the bat does not want to participate in a war between the birds and the beasts. Later, he becomes a turncoat, which results in its rejection from both parties. This causes it to hide in the darkness, act at night, and live in caves (Aesop 2007: 275; Sax 2001: 21). ${ }^{5}$ Similar avoidance is depicted in Ovid's Metamorphoses, and the myth about Minyades - the three princesses who refused to worship Dionysus - so he punished them by making them crazy and transforming them into nocturnal birds and bats (Bats, 2020; Ovid. Met. IV, 1-40; Sax 2001: 22).

The most important source for bats according to Roman writer and official Pliny the Elder was written in his famous encyclopaedia of the ancient world titled Natural History (Naturalis Historia), describing bats as:

Among the winged animals, the only one that is viviparous is the bat; it is the only one, too, that has wings formed of a membrane. This is, also, the only winged creature that feeds its young with milk from the breast. The mother clasps her two young ones as she flies, and so carries them along with her. This animal, too, is said to have but one joint in the haunch, and to be particularly fond of gnats $(\mathrm{NH}, 10.81)$.

The Plinian method has been applied to bats, which also used his own words within encyclopaedic knowledge to take information from various Greek and Roman sources, including lost works. Except for the description of bats, his research on them was

\footnotetext{
4 Among others, it is valuable to mention Australian scholar Tessa Laird from the University of Melbourne, who wrote an interesting and excellent book about bats. Her book is a cross-disciplinary approach and interdisciplinary perspective to the bats, which is realised as a combination of biological, cultural and social analysis of bats. This unique book to the bats put them in the world avoiding speciesism and an anthropocentric perspective.

5 Boria Sax in his book Mythical Zoo: Animals in Life, Legend, and Literature gave an encyclopedic overview of bats, their role in human history and culture. He founded the NILAS (Nature in Legend and Story) in 1989, where participants investigate the relationship between different forms of life represented in literature and folklore (cf. Marjanić, 2017: 126-127).
} 
dedicated to pharmacology, as he has mentioned the magical and medical role of these creatures, including their use of body and blood (NH, 29.26-27; NH, 29.29; NH, 30.46; $\mathrm{NH}, 30.48-49$; comments by Riccucci 2012). His word affected perception of these flying animals in Late Antiquity and the Medieval era.

The bats' negative image continues to exist through the Christian Late Antiquity and the Middle Ages, ${ }^{6}$ as well as the works of Church Fathers such as Eusebius of Caesarea, Saint Ambrose from Milan, and Saint Jerome. The peak of this negativity is represented in Dante's Divine Comedy in which the Devil is depicted as an enormous bat with three faces (Dante, Inf. XXXIV). The short way from supernatural beliefs to real-life events was Lady Jacaume of Bayonne's death, in France in 1332. The reason was that bats were flying around her house and yard. This connection of bats and devils was materialised into a $14^{\text {th }}$ century painting called The Fall of the Rebel Angels, produced by an anonymous artist from the Sienese circle (Laird 2018: 45-46). In the Middle Age bestiaries, the bat (lat. Vespertilio) is described as a bird lacking the feature of nobility because, in comparison to the rest of the birds, it gives live birth to its offspring rather than laying eggs, and it has teeth. The mentioned bestiary explanations, as well as iconographic records in which it is marked as a mouse with wings, are dated from the inscription of Pliny the Elder (Naturalis Historia, 10.81), and Isidore of Seville (Etymologies, 12, 7:36). ${ }^{7}$ Other reasons for prejudice in Medieval times could be due to the taboo against homosexual behaviour; contemporary research shows at least 22 species of bat with same-sex behaviour. The reasons for this could be alloparental care, excitement, social play, and heterosexual copulation (Riccucci 2011: 139-147).

In Slavic mythology, bats have been represented negatively (related to negative spirits or blood, witches, vampires), positively (relation with abilities for fortune, apotropaic) and in duality as a hybrid animal - flying mammals between mice and birds. In traditional Russian beliefs, bats are mentioned as ambivalent according to situations similar to Aesop's tale. In Bulgarian legend and belief narrative, God created bats from fugitives, which further serves as an explanation for nocturnal activities. A transformation from ordinary seven-year-old mice to bat is discussed in Polish folktales. Various taboos are linked with bats caught in human hair. Moreover, based on their blindness, bats have amulet usage and could serve as an addition to clothes for protection and nearby houses. Similar purposes were served in magic and health (Gura 2001: 497-498). ${ }^{8}$

The Serbian Mythological Dictionary (Srpski mitološki rečnik 1970) states that no living being suffers because of its name (in Serbian slepi miš) like the naive bat does. The bat is used in love magic in the Serbian ethno-tradition because of his name, which

\footnotetext{
6 In Cvijet krijeposti, the Flowers of Virtue, the Old Croatian translation of the famous Italian work Fiore di virtù, a bat (šišmiš, netopir, ljiljak, lilik) has been described as an ugly and shameful creature who symbolizes lust, passion, concupiscence, fornication and sexual sins and 'androgyny which is highlighted in the text in the description of his same-sex relationships' (Zaradija Kiš, Šimić 2020: 108).

7 'Bat'. http://bestiary.ca/beasts/beast250.htm

8 Russian folklorist Aleksandar V. Gura, the author of the first systematic research of the symbolism of animals in Slavic folk tradition (as the title of his book suggests - Symbolism of Animals in the Slavic Folk Tradition, 1997), is a writer of lexicon article on the role of a bat in Slavic ethnotradition (Gura 2001).
} 
means blind mouse. The definition of blind is not literal; in contrast, the animal is blinded in daylight and it symbolised the person in love as bewitched. As a consequence, the bats were caught, and the lovesick person attempts to get to bats' wings and bones; then dried, crushed to a powder, and placed in the food and drink of the person to be loved, so that that person would blindly fall in love with the one who applied the magic or the one for whom the magic is intended. In addition, an enamoured human wore a bat's wing as an amulet (Petrović 1970: 268), as noted by Aleksandar Gura (2001) for Bulgarian and Macedonian beliefs.

Early modern travellers, explorers and colonists of the New World referenced bats in a negative perspective. In his visits to Latin America, Girolamo Benzoni described these animals by writing about his experience with bats biting his extremities (legs, feet, arms, hands). A similar negative reference described Australian bats as devils by early Europeans from James Cook's crew (Laird 2018).

Folklore stories from North America have been conducting bats in different sources. In Nova Scotia, bats are described as a vision of death, and when the bats fly around in the house a female from the house will die. If a bat lands, a male will pass away. Similar folktales are found from parts of the United States of America. In Illinois, a bat will bring death in the house if s/he stays a longer time. If s/he stays is shorter, some relative will die while in New Mexico, the death in the Midwest will be in a few days or month/six months, and in Washington the death will be within a year. The child's death is foretold in Californian superstition in which the child will pass away if his pregnant mother watches a bat. Furthermore, as Gary F. McCraken pointed out, in other American areas, dreaming of these animals flying around house in combination with dog's howling represents a premonition of death within a person's home, relative or a friend (Bats 2020).

One of the stereotypes about bats has been related to stealing food, particularly bacon and ham. These ideas spread throughout Europe and America during early and modern periods. According to Allan's research from 1939, he further exemplifies this point by: 'describing experiments conducted in Germany in the early nineteenth century in which captive bats were offered a diet of bacon, but the bats often refused it and starved to death' (Bats 2020; Laird 2018: 80).

In the later popular culture, bats were linked with vampires, Halloween, and the popular comic hero Batman, which is the result of Bram Stoker's Gothic horror novel Dracula (1897) and his introduction of correlation between bats and vampires in the context of the political situation at the end of the $19^{\text {th }}$ century. ${ }^{9}$ The representation of bats as bloodsuckers arose with Bram Stoker's Dracula along with a film version played by Bela Lugosi (Fenton, Ratcliffe 2010). This depiction has been raised in Francis Ford Coppola's movie titled Bram Stoker's Dracula, in which the main character, performed by Gary Oldman, appears in a demonic form of a bat which has been finalised into an evil demon who escaped from the dead body of Dracula (Laird 2018: 58-59). Simultaneously, bats are depicted as beings

\footnotetext{
9 The most important element for Stoker's fantasy is contagion (Perić, Pletenac 2015). Boris Perić and Tomislav Pletenac discussed Stoker's novel's political background and detect the Eastern (Balkan) Question as the critical factor for British foreign policy and politics at that time. The main issues were integrating and regulating of post-Ottoman Balkan into new political entities (Perić, Pletenac 2015: 19).
} 
on the border of worldly and otherworldly, which are shown trespassing this border on Halloween night (Kunz 1984). Ultimately, the comic and movie hero Bruce Wayne, known as Batman, chose the bat for his trademark after being prompted by his childhood trauma of falling among bats, highlighted in the film Batman Begins, from 2005, by Christopher Nolan. With the iconographic use of the bat, the dark cave, and the nocturnal life through which the hero Batman additionally attempts to make the villains even more fearful.

This depiction of a hybrid human and bat in the form of a superhero could be analysed on three levels. The first level is psychological, dedicated to fear and trauma, which acts as a symbol of fear translated to personal strength. This transformation of fear could depict Jungian psychoanalysis, along with Jung's remarks about the shadow. This term can be defined as unconscious, relating to the different positive and negative hidden aspects of personality and life. As Jung wrote: 'Everyone carries a shadow and the less it is embodied in the individual's conscious life, the blacker and denser it is' (Jung 1938: 131). Following this quote about bats in Bruce Wayne's context, his fear of bats became the primary source for his power because he enlightened his shadow and removed anxieties and false beliefs about himself.

The second part is the social perception of bats, one that recognises these creatures as strange, dark, and scary creatures. Instincts, according to Jung's research, relate to the animalistic part of human personality, and it is critical to understand bats in the context of basic instincts. This combination of instincts and defensive mechanism, particularly the sublimation of his revenge and aggressive behaviour to useful social appearance, have made Bruce Wayne a unique character who came from the dark and saved the world as a superhero (Kiatpattananon 2017). The uniqueness is comparable to bats. which are the only mammals capable of flying.

The final piece is the potential subversive, because non-heroic animal - bats - represent Batman as the hero and this would improve the status of bats in society and culture. ${ }^{10}$ Rather than causing harm, bats became powerful and visually linked with Batman, Gotham City's protector.

Contemporary artists have used bats in their installations, stage performances, or artworks. The most valuable group to mention here are Samoans: writer Albert Wendt with his story Flying Fox in a Freedom Tree, photographers Greg Semu and Yuki Kihara, painter and poet Dan Taulapapa McMullin, artists Lin Onus, Robin White, Julian Hooper, Kathy Holowko and Helen Pynor. These artists are mostly from Australia and Oceania, and their works are a combination of local myths and traditions in the context of contemporary art. Artists from other parts of the world, such as American artists Tim Hawkinson, and Brits Marvin Chetwynd Gaye and Jeremy Deller, have experimented with depictions of bats (Laird 2018).

\footnotetext{
${ }_{10}$ At the moment, it is valuable just to mention potential subversive role of bats in context of Batman and suggest further social and psychological research on these topic, although we need to have at least two part in the minds: a) representation of Batman and bats is not linear in the history of this fictional character and changed during time and social context; b) comparison on the line Batman - bats could be Spiderman - spiderman which could open similar research issues; c) correlation between popular male characters such as Batman, Spiderman with females like Catwoman.
} 
The most controversial performance was Ozzy Osbourne eating or biting a bat on the stage in 1982 during a concert as he ate the head of (probably) a live bat (Andrews 2019, 2020; Laird 2018).

In his autobiography I am Ozzy, he wrote a detailed story about this event (Osbourne 2010: 153-154). Although media speculations have been challenging the idea of live animals and Mark Neal, a seventeen-year-old fan who brought the bat to the concert and threw s/he to the stage, reported that the mammal was dead before a concert, Ozzy denied this and continued to speak about a live bat (Andrews 2019: 2020). The concert sparked considerable media interest around world and a great deal of controversy. Several protests emerged, organised by the American Society for the Prevention of Cruelty to Animals, and fans began bringing various strange items to the stage. Two main ideas could be understood from this unusual situation: medical ideas about rabies from bats which could make some kind of narrative in contemporary society, and Ozzy's attitude to animals, which is unacceptable and even a crime. The former will be discussed later and understood from the experiments and testing bats to rabies. The latter is related to animals in performance art as shocking and provocative items, because the bat is not realised as being or animal and has rather been present as an artefact or item.

An exciting approach to bats is written in the book Raising Archie with the subtitle 'The story of Richard Morecroft and his Flying Fox' by Australian journalist Richard Morecroft, which has been recorded as a short documentary in which Morecroft spoke about his experience with an orphaned bat, Archie. His advocacy of promoting wildlife and saving the threatened animals, such as bats, could be positioned within Native Australians or Aborigine cultures and their relation to the flying mammals. The stories about bats and Aborigines are highly complex because bats have been presented both positively and negatively. One side of the story is related to the Balayang and Tjimin. In the first side, bats are the opposite of the owl and are part of the soul. The second - Tjimin - is related to the Great Rainbow Serpent and humanity's ancestors.

Other tales expressed more negative approaches. The story of Naradan was of a half man-half bat who lived in Dreamtime (analogous to Heaven in Western interpretations). One day, his wife went to the forest to buy honey for him. When her arm became stuck in a tree, he came, cut her arm off, and she died. A similar story happened to his other wife, and he was thrown into a great fire where he became a bat and disappeared into the dark. Naradan lives as shamed being - a bat - and hides during the day. A different gloomy tale about bats can be related to a handsome man punished by gods in which he transforms into a creature - a rat with wings - and sleeps under the bridge with his head down ${ }^{11}$ (Grenoble 2020).

These links between humans and animals have been described by Deborah Bird Rose as the 'entangled mutuality' that Aborigines have in their interactions with bats. Today, Indigenous Australian communities of the Northern Territory have rejected these interactions (Laird 2018). The ties between humans and bats in various relationships and

\footnotetext{
${ }^{11}$ It is valuable to mention the source for these stories, which is a children book produced in France and written as a dialogue between a Native Australian person named Bunna and a journalist (Grenoble 2020).
} 
combinations of positive and negative approaches take steps in building integrating views to nature and environmental justice that have been immanent to Aborigines, people of pre-colonial Australia. These traditions should be re-invented through contemporary conservationists in Australia and the story of how Morecroft and Archie could bridge this gap.

The following table is a comprehensive review of the bats in the world mythology, and the bat is analysed as a representation of certain feelings, events, or beings which could be matched with Lévi-Strauss and his idea of species of animal or plant which have been identified with certain groups in the context of totemism (Lévi-Strauss 1963). From the table below, it is possible to understand different political entities and geographical areas where a bat is related to mainly positive emotions, events and thoughts. These terms have been related to the mythological perception of bats and understanding these flying animals in ancient people's worldview.

Table 1. Representation/symbolisation and meanings of bats

\begin{tabular}{|c|c|c|}
\hline Culture & Representation & Meaning \\
\hline Chinese & luck & positive \\
\hline Japanese & luck & positive \\
\hline Hindu & sacred animals & positive \\
\hline Pacific & fertility & positive \\
\hline African - Kenya & luck & positive \\
\hline South American & help, sharing of knowledge & positive \\
\hline Native America - Navajo & speech, god helpers & positive \\
\hline Mesoamerican & death & negative \\
\hline Greco-Roman & duality & negative \\
\hline Late Antiquity & evil & negative \\
\hline Medieval & evil & negative \\
\hline Slavic & evil spirit, amulets, fortune & ambivalent \\
\hline Early Modern travellers & evil, annoying & negative \\
\hline Modern Western & death & negative \\
\hline Halloween & border animals & negative \\
\hline Dracula & vampire & negative \\
\hline Batman & fear & subversive \\
\hline Native Australians/Aborigines & fertility, death, shame, punishment, isolation & ambivalent \\
\hline
\end{tabular}

After all, the mythological and the popular culture representations of the bat could be summarised in a few common parameters: a) night and avoidance of the light and sunlight, b) fear, uneasiness, and punishment in European, American and Central American 
depictions, c) luck, longevity, and helpfulness in stories and legends of Chinese, Indian, Japanese and Pacific origin, d) duality of the beings - as mice, and as birds. The last part is important because modern science has rejected bats as mice or birds and rather classifies these creatures in other classification while fruit bats have been considered the same as flying foxes. The terminology for these mammals still derives from the combination of bird and/or mice, which is used in a plethora of languages, including South Slavic Croatian terms šišmiš (netopir, netopijer, liljak), ${ }^{12}$ the Slovenian word netopir, or Serbian slepi miš for a bat.

It seems that in the Eastern and the Western world, as we call them, the variety of approaches towards the bats can be explained with the idea of contemporary philosopher Ji Xianlin about the diversity of opinions, where the Eastern would be synthetic - meaning intriguing, including nature, and all the matter (based on Confucian and Taoist perceptions of the world), while the Western opinion would be analytic - meaning disambiguating, violent and aggressive towards nature (Ji Xianlin 1997: 82-84). Applying this knowledge, it is clear that the bat in the West is presented as the Other, while in the East (in Polynesia, India, Japan as well as China) s/he is depicted as a part of nature, and consequently, as a part of the human world. The potential biological reason could be in echolocation, which is not used by fruit bats, based in East Asia. Also, these animals are extremely important for seeding dispersal and agriculture in Asian cultures. These elements would affect cultural depictions, and this could be a way for understanding positive myths about bats in some parts of the world. The Chinese word for bat is $f u$ (蝠) and it has similar pronunciation as the word for happiness (also $f u$, but different character 福) that could be matched by Ji Xianlian's idea of synthesis and ancient Chinese link bat with luck which affect perception and recognition of these flying mammals.

These ideas could be matched for the Western world with the concept of hyperseparation, which is developed by Val Plumwood. This idea is understood as a binary opposition between two entities divided by strong and separate borders, improving differences and binarity instead of similarity. As a consequence of mentioned thoughts that started in the Enlightenment period, there is a decline in animal ethics and the potential rise of violence against animals and others (Miller 2016; Plumwood 1993). Comparative thoughts and ideas to Plumwood analysis were expressed by Branislava Vičar and her concept of the animal world as transcendental otherness, then Claude Lévi-Strauss and his conclusion about totems as part of the distinction between culture and nature and finally, Philip Armstrong and Laurence Simmons with terms such as 'humanness, inhumanity, compassion, sentiment and beastliness' in contrasting humans and others (Vičar 2013: 40; Simmons, Armstrong 2007: 1-2; Lévi-Strauss 1963). The basics of these binaries could be developed as humans and bats. The former could be presented as positive while the latter would be defined as negative, and can be applied to modern popular culture, such as Dracula and Batman. In the context of bats in mythology, these concepts of hyperseparation with a combination of synthetic and analytic perceptions of the world could be a way of understanding bats in historical and mythic perspectives that will contribute to the modern ideas about bats.

\footnotetext{
${ }^{12}$ On bat etymology in Croatian language, cf. Tvrtković 2017: 10-12.
} 
Nowadays, perceptions about the bats are handled in an interesting article written by the Slovak researchers Pavel Prokop, Jana Frančovičova, and Milan Kubiatko, published in 2009. They conducted research using their questionnaire Bat Attitude Questionnaire (BAQ) among Slovak students (Prokop, Franchovichova, Kubiatko 2009). Their claims (the connection of knowledge and beliefs in the narratives about bats) concur with reflections of Matchett and Davey, who categorise bats as repulsive animals together with cockroaches, spiders, and rats, in order to develop a hypothesis about the avoidance of infection, which is based on (1) fear of animals linked to infection, such as mice, rats, bats, and even a pigeon (2) fear of animals linked to mucus or faeces, for instance, snakes, worms, or snails, (3) fear of animals related to dust, disease, or infection, such as spiders (Matchett, Davey 1991, c.f. Prokop, Franchovichova, Kubiatko 2009: 20; Nagy, Johnson II 2013: 10). ${ }^{13}$ An additional reason for the fear of bats is the media representation that caused an ingrained belief according to which bats are rabid, even though the testing conducted by Whitaker and Douglas, when they tested 8262 bats, showed that only 5.4 $\%$ tested positive for rabies (Whitaker, Douglas 2006: 1569-1573 c.f. Prokop, Franchovichova, Kubiatko 2009: 20). Moreover, Friedrike Mayen determined that only three out of more than one thousand species of bats feed with blood; therefore, they do not represent a threat to humans (Mayen, 2003, c.f. Prokop, Franchovichova, Kubiatko 2009: 20).

In contrast to bats as animals with a plethora of diseases, traditional medicine, as mentioned in the ancient world such as Papyrus Ebers from 1500 BC in ancient Egypt, has used bats as curators and sources for medical treatments developed in India and China. The medical text Papyrus Ebers has mentioned bats' blood to recuperate skin, hair and eye diseases. Different medical usage of bats has been recorded in texts from Roman and medieval Egypt, Algeria, Senegal, Benin to early modern states of Italy, England, Sweden, Switzerland and various North, South American and Asian countries. As a voice of re-usage for traditional medicine, Marco Riccucci promotes sustainable using bats for chitin and chitosan (Riccucci 2012: 249-270).

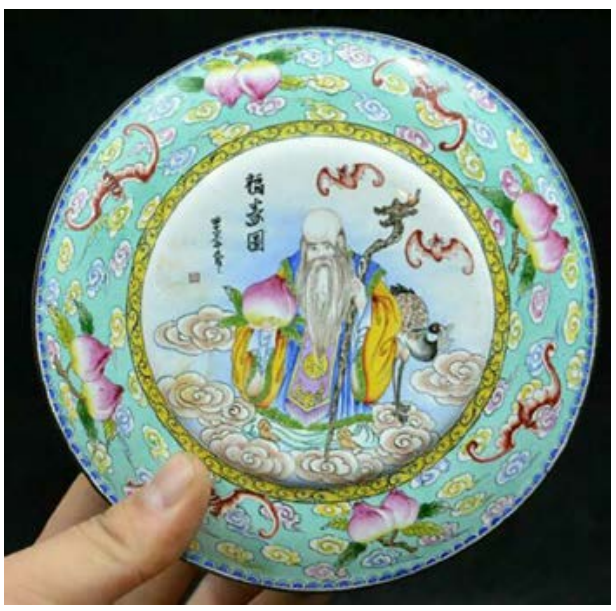

Fig. 1. Shouxing, Chinese god of longevity, together with two bats (source: https:/www.ebay.com/itm/ Old-Chinese-Bronze-Cloisonne-Enamel-Shou-XingBat-Bijou-Jewelry-Casket-Box-/254346795985). The pair of bats is a sign of deity for longevity Shouxing and symbolised positive and good wishes (Cooper 1986: 151). In East Asia, particularly in China, the word for bat (蝠) shared pronunciation with the word for happiness (福), and it is $f u$. The five bats represent Five Fortunes (wu fu, 五福): wealth, longevity, peace, health, and positive death (Chevalier, Gheerbrant 1987: 677).

\footnotetext{
${ }_{13}$ In the book Trash Animals, Kelsi Nagy and Phillip David Johnson II (2013) analysed different cultural identities of animals that affect their representations even if humans, as Thomas Nagel pointed out, have not understood real animal experiences.
} 


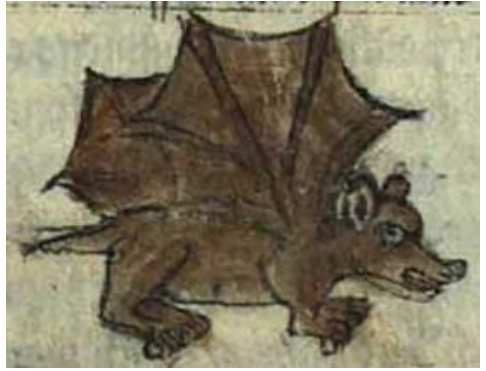

Fig. 2. Angry, little brown bat, in fact, a mouse with wings. Perhaps, the bestiary attempted to indicate that it has teeth. Kongelige Bibliotek, Gl. kgl. S. $16334^{\circ}$, Folio 42v (Source: http://bestiary. $\mathrm{ca} /$ beasts/beastgallery250.htm\#).

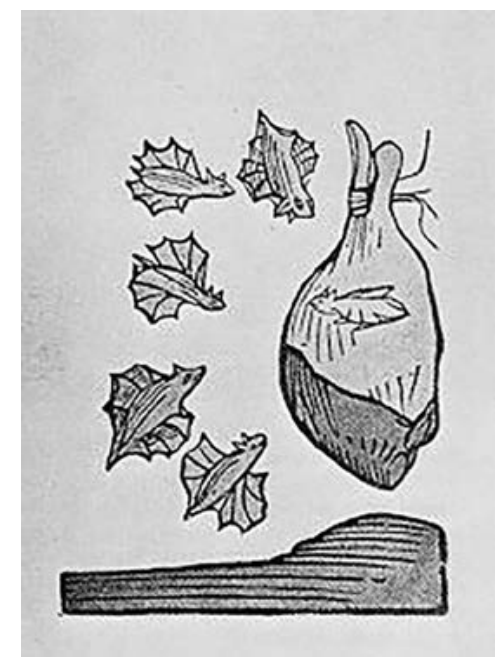

Fig. 4. Woodcut from 1491 with a representation of bats and their eating of meat (ham and bacon), although these food habits have not been proved, and it could be prejudice (Laird 2018: 78; source: https://www.batcon.org/article/bats-in-belfriesand-other-places/)

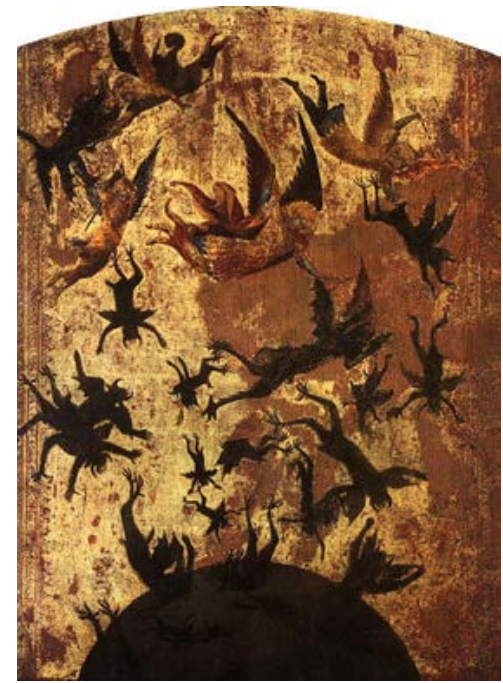

Fig. 3. The Fall of Rebel Angels (Master of the Rabel Angels), Oil painting from $14^{\text {th }} \mathrm{c}$. (Laird 2018: 48).

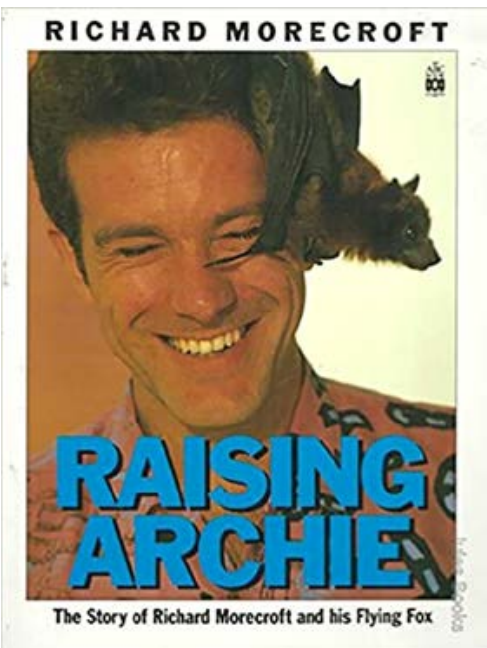

Fig. 5. Richard Morecroft and Archie (source: https://www.amazon.com/Raising-Archie-RichardMorecroft-Flying/dp/0731802543). 
The main question is the lack of empathy towards these animals. The explanation of the issue lies in ignorance about their anatomy, behaviour, and habits, which creates narratives, myths and, in the end, fear that leads to the decrease of the bat population in the world. Bats are one of the most endangered species in the contemporary world, resulting from usage in traditional medicine and food in the East and demonisation in the West.

Goran Đurđević

\section{OF FICTITIOUS AND ENDANGERED BATS, ALLEGED CATALYSTS AND CARRIERS OF THE CORONAVIRUS FROM WUHAN, OR, WHAT IS IT LIKE TO BE A BAT DURING THE COVID-19 PANDEMIC ${ }^{14}$}

The scientific version of the story about the bats related to the Covid-19 disease, according to Mirjana Žagar-Petrović, MD, claims that 'the new coronavirus named 2019-nCoV was discovered in humans, in China, for the first time by the end of the last year. It causes a disease similar to SARS, and the disease it causes is called Covid-19 (CO - corona, VI virus, D - disease, 19 - year 2019). Scientists still cannot confirm which animal was the catalyst and the carrier of the coronavirus from Wuhan' (Žagar-Petrović 2020). However, it is presumed that it could be the bat. Most coronaviruses affect animals; nevertheless, zoonosis, as a disease, is passed from animals to humans.

Recent epidemics caused by that virus were Severe Acute Respiratory Syndrome (SARS) from 2003, and Middle East Respiratory Syndrome (MERS) from 2012. The research showed that humans were infected with MERS after being in contact with camels, while SARS was brought to humans by viverrids. [...] The principal hosts and transmitters of the coronavirus are bats, which can carry the virus to other animals, such as Chinese ferret-badgers, racoons, and viverrids. It is believed that the infection originated at Huanan Seafood Wholesale Market - a live animal and seafood market, after consumption of the food at the market, and after handshakes, which led to the commence of human-to-human transmission (HHT) (Žagar-Petrović 2020).

Therefore, we should not overlook the evidence that the early cases of Covid-19 occurred outside of Wuhan in China, and that they did not have a clear connection with the city's wet market, which is considered the place of its onset (Nunez 2020; Hayes 2020).

It is noticeable how this 'infectious' story is not bringing along deeply environmental narrative concerning the alleged process in which a Chinese bat in the metonymic Chinese soup becomes the cause and the transmitter of the coronavirus from Wuhan. This deeply

\footnotetext{
14 The second part of the text, written by S. Marjanić, is part of the project Cultural animal studies: interdisciplinary starting-points and traditional practice-ANIMAL (IP-2019-04-5621), Croatian Science Foundation.
} 
environmental story is similar to the plot of Steven Soderbergh's film Contagion from $2011,{ }^{15}$ which concerns the spread of a lethal virus that causes a global pandemic in a matter of weeks. The film's final sequence reveals the culprit of the origin. In the context of the fictitious virus from Soderbergh's film, which is considerably more dangerous, and cannot be related to Covid-19, I would like to put emphasis on Wilson's concept of the unity of knowledge that is indispensable in a comparative analysis of the mass media information, and so called, kynical conspiracy theories that undermine the cynicism of power in government - in Sloterdijk's denotation of kynicism, as well as in the denotation of political scientists. As the World Wildlife Fund's research demonstrates, ${ }^{16}$ the first step in causing a pandemic is deforestation, after that comes live animals trade, and then there comes the wet market ${ }^{17}$ where different species come in contact. That would be a concise journey of the pandemic, which is not mentioned in the mass media since it is an ecocentric, biocentric story that contradicts the global speciecist neoliberal economy. In that regard, we can end with the prediction of the GMO prophet of apocalypse, Árpád Pusztai, who says that the 'world will not be destroyed by terrorists, but by scientists' (cf. Pusztai 2011).

Regarding the already mentioned zoo-partaker as the claimed catalyst and transmitter of the pandemic, I would mention the research of Leonard Schild and his associates, who affirmed that the Covid-19 is encouraging online Sinophobia, ${ }^{18}$ and that the sharing of the Sinophobic content is a multiple phenomena on social media: it can be found in marginal online communities, as well as on politically incorrect platform 4chan, and up to a certain degree on common platforms, such as Twitter (Schild 2020: 1). In contrast, the statements of senior officials, such as American President Donald Trump, about the Chinese virus, or the statement of French President Emanuel Macron regarding Chinese and Russian authoritarian regimes and Western democracy, as well as the statements of famous researchers such as American sinologist Jeffery Wasserstrom who, back in December, wrote about hiding the first cases of infection, later on, the statements of British think tank Henry Jackson Society that wrote about concealing and falsifying information, only to, at the peak of those occurrences, find their place in the mass media, such as The Guardian, The New York Times, Sky News Australia, and many others (Zhang Yunpeng \& Fang Xu 2020: 211-223). Such politicians', scientists', and journalists' demeanour and false, unfounded statements in the form of fake news and post-truths contributed to the rise of Sinophobia during the coronavirus pandemic.

\footnotetext{
${ }^{15}$ Kevin C. Moore points out that, in addition to being an example of the perennial outbreak narrative, 'Contagion also represents the $21^{\text {st }}$ century media logic of what Grusin (2010) calls "premediation" or "medial pre-emption" that developed in the post-9/11 moment, of which Contagion is most certainly apart' (Moore 2020: 3).

${ }^{16}$ Source: https://www.wwfadria.org/hr/novosti/covid_19_i_bioraznolikost/

17 They are called 'wet' since vendors often slaughter animals in front of customers. It is noticeable that the first news about Covid-19 was fake news about the wet market in Wuhan being the cause of the pandemic (Cohen, 2020).

${ }_{18}$ During the Covid-19 pandemic, the Chinese influencer Wang Mengyun had to apologise for the bat soup she was eating in Palau, in Micronesia three years before the start of the pandemic, which was a photo segment for her vlog, cf. O’Neil.
} 
Sinophobia and influencer Wang Mengyun's apology descended from the ecocentric, zoocentric perspective to the bat's experience, not only in the Chinese soup in which it ended up as a meat victim, but as a demonised media victim in the infectious Covid-19 story. In the context of the previously mentioned, I will refer to the book Being a Beast from 2016, written by British veterinarian and philosopher Charles Foster, in which he wanted to know what it is like to be a wild animal. The book is a representation of his intention to live in a cave in Wales, as a badger, for six weeks. The experience of being an animal is marked by nudity and cold; he is eating insects, worms, and road kill (Svendsen 2019: 93). In 1974, American philosopher Thomas Nagel, wrote an article on 'bat phenomenology' in which he wondered what it is like to be a bat; he claims that neuroscience will never bring us closer to the comprehension of the mentioned experience, and that applies to all the other external research of animals. Nagel's influential article What Is It Like to Be a Bat? (1974) goes to the essence of the problem, and that is the question of the consciousness (qualia). Namely, as much as we research, even if we have all the information about bat's brain architecture, we cannot know what the bat experiences in the times of pandemic. ${ }^{19}$

On April 14 $4^{\text {th }} 2020$, the association Animal Friends Croatia, published on their webpage the following news ${ }^{20}$ about a group called NOVID-50 that commenced with around 20 people who tried to create a solution for Covid-19 crises, on Global Hack - an online event where teams from all over the world are bringing forth practical solutions in a $48 \mathrm{~h}$ timespan. NOVID-50 deals with the cause of pandemics caused by diseases transmitted by animals, but the emphasis is on intense animal exploitation (for instance, Charles Patterson claims the industrial strategy to be a holocaust). They are appealing to the United Nations to create a strategy for termination of work for industrial animal farms, live animal markets, as well as the overall exploitation of animals. To summarise, the association highlighted the deeply environmental catalyst of the pandemics, among which we have the meat diet - or as Melanie Joy would say - the ideology of carnism.

It is noticeable how the information that certain animals are detrimental to human health came along with the pandemic: the so-called wet markets were linked with Covid-19, the emphasis was put on swine flu, bird flu, MERS (camel as the demonised catalyst), mad cow disease (cf. Gellatley 2001: 89), and SARS (bats and reptiles as the

\footnotetext{
${ }^{19}$ Cf. the reflection on Nagel's bat text/essay, 'which is one of the most oft-quoted works on the problem of consciousness, particularly within the field of human-animal relations', in J. M. Coetzee's The Lives of Animals (Coetzee 2004; Laird 2018: 143-144). Wendy Doniger, as one of four real-life respondents to Coetzee's academic novel, suggests 'that Nagel probably chose a bat rather than a horse "to make the point of non-communication more dramatic, because we don't love bats"' (cf. Laird 2018: 144). Personally, we dare say - along the lines of Nagel's definition, due to which he takes the bat into consideration as regards consciousness - perhaps we may not deal with Wendy Doniger's definition, but rather with a specific 'bat phenomenology'; it is the only flying mammal, and communicates by echolocation (sonar) - i.e., it creates a spatial image in-flight by listening and analysing the rebound sound (echo), and assumes a reverse, suspended position when resting - it hangs upside down. Specifically, Elizabeth Costello, who is considered J. M. Coetzee's fictitious alter ego in the novel The Lives of Animals, defines Nagel's essay What Is It Like to Be a Bat? (1974) as tragically restrictive due to the lack of the domain of zoo-ethics (Coetzee 2004: 36, cf. Mulhall 2008: 23-24, 33-34).

${ }^{20}$ Cf. Petition against animal exploitation; http://www.prijatelji-zivotinja.hr/arhiva.php/?id=5985
} 
demonised catalysts), wherein PETA proclaimed its vegan billboard about meatless diet, metonymical tofu, which never caused a pandemic. ${ }^{21}$

Merlin D. Tuttle, a scientist and the founder of Bat Conservation International, the manager of Merlin Tuttle's Bat Conservation, in his article Give Bats a Break from 2017, emphasises that the search for new viruses in bats probably would not significantly contribute to the human health, but it could seriously jeopardise bats' future. The summary of the mentioned article: the idea that the bats could be responsible for the transmission of the new lethal infection to humans, started in 2002 with the discovery of the new coronavirus that caused serious respiratory infections named SARS. Coronaviruses are widespread among animals; they cause colds; however, in 2002, SARS was the cause of death of around 800 people. Three years later, an article in Science, called Bats are natural reservoirs of SARS-like coronaviruses, announced a public lynching for bats, considering the fact that the scientific proclamation was that bats are a global threat to public health. From that point on, the socalled virus hunters have conducted an intense search after the dangerous bat viruses. In the

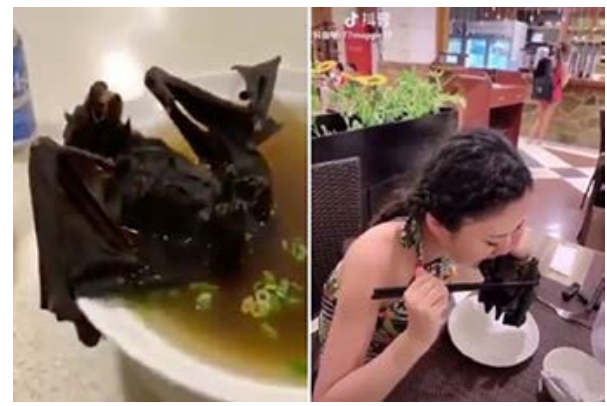

Fig. 6. Chinese blogger Wang Mengyun and bat soup, albeit not in China, but in Palau, Micronesia (source: https://www.news.com.au/lifestyle/food/ food-warnings/chinese-influencer-wang-mengyunaka-bat-soup-girl-breaks-silence/news-story/63ef0 cec5b6d448d1843e2e1bcadb14d).

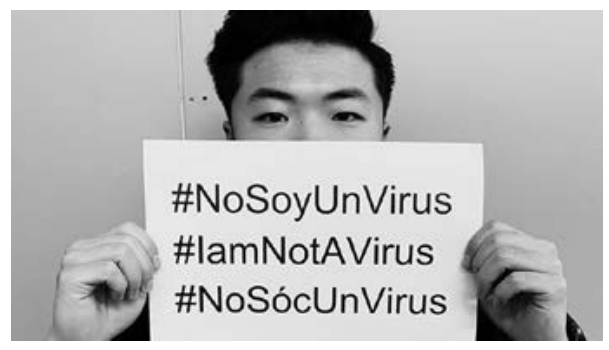

Fig. 7. An example of a reaction to Sinophobia during the pandemic (source: https://news.berkeley. edu/2020/02/12/coronavirus-fear-of-asians-rootedin-long-american-history-of-prejudicial-policies/). context of that chapter, the author raises the key question about whether we should start to worry about our conduct towards bats on behalf of science and public health. Tuttle further claims from the point of his ecocentric view that it is impossible that the bats participated in the infection emergence, considering the fact that for most of human history, we lived in caves, then in straw huts and shacks, and that implied living with bats. However, in recent centuries, the trend reversed. Due to the industrialisation, the bat population decreased, and modern people started to live in buildings that exclude bats from their habitat. Bearing in mind the long history of our close connection, it is comprehensible that we developed an extraordinary resistance towards each other regarding diseases. That might be the explanation of why it was so difficult to document bats as the sources of infections among people, and why is it crucial to eradicate the demonisation of the bats (Tuttle 2017: 44). In that respect, I consider Tuttle's zoocentric article the finest response to Nagel's philosophical and rhetorical question from the perspective of 1974 .

\footnotetext{
${ }_{21}$ Source: https://www.independent.co.uk/news/world/americas/peta-coronavirus-billboard-tofu-pandemic-animal-rights-iowa-a9532716.html
} 


\section{APPENDIX: BATS ON DISPLAY IN ZAGREB}

In his book Animal Theology, Andrew Linzey notes that the United Kingdom's Wildlife and Countryside Act of 1981 accords the bat specific legal protection and stresses that ' $[\mathrm{w}]$ hat is interesting about this legislation is that not only are bat rights upheld by law, but also even in competing situations with human rights, the bat is to be given preferential treatment' (Linzey, 1994: 42). However, the aforementioned UK act, according to which bats are given more rights than humans, is evidently an isolated case in terms of its deliberations regarding bats, which are considered even today one of the most victimised and least studied animals. Specifically, contemporary infectiology papers mostly point out that the uncharted territory of the bat's role in the occurrence of certain diseases has only just begun to be studied (Calisher 2006: 149-155). Thereby the role of the human factor (e.g., the aforementioned deforestation) is not accentuated, while the fact that bats are extremely useful animals is frequently omitted, as pointed out by, for example, Snježana Vujčić-Karlo, Senior Curator and Head of the Natural History Department of the National Museum in Zadar. Apart from eating insects (mosquitos, flies) in the ecological chain, which helps prevent malaria in numerous parts of the world, bats are also pollinators of some plants.

Let us present in more detail two exhibitions on bats, organised in Zagreb in 2019 and 2020. The exhibition Technologies in Biology: Bats (Tehnologije u biologiji: Šišmiši; Zagreb, Nikola Tesla Technical Museum, 2019) ${ }^{22}$ featured technologies disclosing the hitherto unknown experiences of bats, nearly in the sense of Nagel's paper What Is It Like to Be a Bat? The exhibition is the result of a two-year research on bats on the island of Lokrum near Dubrovnik (Public Institution Lokrum Reserve) ${ }^{23}$ with particular regard to two species of bats (i.e., Plecotus kolombatovici and Rhinolophus hipposideros). The exhibition linked the world of bats and the technology (bat detector, telemetry) used for studying the former with specific objects (e.g., the reproduction of da Vinci's drawings that elaborated the idea with which he conceived a human flight apparatus by studying the wings and flight of bats; Slavoljub Penkala's model of another, subsequent variant of a plane - TMNT 1852; the small Italian submarine CB-20, produced in Milan, Italy, in 1943 - TMNT 332) from the permanent collection of the Nikola Tesla Technical Museum in Zagreb. ${ }^{24}$ The exhibition placed special emphasis on echolocation, same as Nagel with his paper that poses the question 'What is it like to be a bat?' from the philosophical niche. As stated by the exhibition authors, 'echolocation enables bats to orientate themselves in space with the help of rebound echoes from their calls. A device which enables the confirmation of the presence of bats by converting their sounds, i.e.,

\footnotetext{
22 The exhibition was authored by Katarina Ivanišin-Kardum from the Nikola Tesla Technical Museum, Marija Crnčević from the Public Institution Lokrum Reserve, Daniela Hamidović from the Croatian Biospeleological Society, Henry Schofield and the Vincent Wildlife Trust from the United Kingdom, and Dina Rnjak from Geonatura, d.o.o.

${ }^{23}$ For more details on the exhibition, cf. the exhibition catalogue and https:/www.lokrum.hr/blog/vijesti/ tehnologije-u-biologiji-sismisi-2/\#. I retrieved all data on the exhibition from the two aforementioned sources.

24 The study of bats on Lokrum by using contemporary technologies such as the application of the bat detector and telemetry has been documented in film, i.e., Boris Krstinić's on-site film. I would like to acknowledge $\mathrm{Mr}$ Krstinić for enabling me to see his film again.
} 
echolocation, into sound that a human can hear, is called an ultrasound detector or bat detector. ${ }^{25}$ In that sense, we can say that the bat detector enabled a partial answer to Nagel's question 'What is it like to be a bat?'

The second research study on telemetry was conducted with tiny radio transmitters attached to individual bats during the research, which the bats shed after approximately ten days. Within this period, the researchers (equipped with radio receivers and directional aerials) can track bats and determine their position in nature. The collected data are processed, and the bats' movements are mapped, as also shown by the map displayed at the exhibition. As mentioned above, the exhibition also showed the manner in which the flight of bats was used by certain scientists in their research. By studying the bats' flight and wings, Leonardo da Vinci was thus the first to elaborate the laws of flight (Visković 1996: 255-256). ${ }^{26}$ Reproductions of da Vinci's drawings elaborating this idea are found in the permanent collection of the Transportation Department of the Nikola Tesla Technical Museum. ${ }^{27}$ Furthermore, the studying of bats and their orientation in space via echolocation also contributed to the development of radar and sonar. Just as bats produce sound that spreads as a wave, these devices (as we could learn from the exhibition captions) transmit and receive reflecting waves, on the basis of which it is possible to calculate the distance and velocity of objects such as submarines, airplanes, and similar. It is a well-known fact that Nikola Tesla also contributed to the invention of the radar.

The second Zagrebian exhibition that featured bats as zoo-actants, entitled Open-Living Beings and Their Dangerous Liaisons (Otvoreno - Živa bića i njihove opasne veze), presented works produced within the European network EMAP - European Media Art Platform that brings together European organisations and institutions dedicated to new media art, and was organised within the framework of Touch Me Festival (Nikola Tesla Technical Museum in Zagreb; KONTEJNER curatorial team, Tereza Teklić and Olga Majcen Linn). ${ }^{28}$ At the aforementioned exhibition, Daniela Mitterberger and Tiziano Derme (MAEID Büro für Architektur und transmediale Kunst) presented their work The Eye of the Other III 'On Flowers' - Interspecies Communication Human/Bats (immersive audio/visual surface, multimodal sculpture, 2019-2020). To quote the artists themselves, The Eye of the Other 'is a project that explores non-verbal communication between humans and bats through studying and translating the bats' sensorial systems. The work translates the perceptual world of nectar bats into perceptual patterns that a human can understand - from echolocation to our senses such as hearing, seeing, and touching.' Specifically, the nectar-feeding bats find flowers by sorting the environment with visual and sonar information. They can recognise the geometry of an individual flower by producing so-called 'echo-imprints'. The project The Eye of the Other III 'On Flowers' translates these imprints into auditory frequencies

\footnotetext{
${ }^{25}$ The bat detector is a device used for detecting the presence of bats by converting their ultrasound signals into sound frequencies.

${ }^{26}$ Leonardo da Vinci's flying machines and ships are early examples of drawing from nature in engineering and as a forerunner of contemporary bionics or biologically inspired engineering (Visković 1996: 255-256).

${ }^{27} \mathrm{Cf}$. http://museums.hr/en/exhibition/details/7638/tehnologije-u-biologiji-sismisi

${ }_{28}$ Touch Me Festival (Zagreb, Croatia) is organised by the curatorial team KONTEJNER. https://www.kontejner.org/projekti/touch-me/-7-doticemo-nove-buducnosti/
} 
and visual, sensory patterns that are understandable by human senses; briefly put, they translate the experience of bats into that of humans. The artists-scientists thereby refer to the theoretical concepts of Jacques Derrida in The Animal That Therefore I Am (2002), Giorgio Agamben in The Open: Man and Animal (2004), French sociologist and science studies scholar Bruno Latour and, naturally, to Nagel's philosophical deliberation 'What is it like to be a bat?'. They defined the encounter with the world of these flying mammals in the following manner: 'Within this space we lose our individuality, we do not count as species but as agents placed in resonance within the environment. Perhaps these types of experience are a direct invitation to question our position as species among the many on Earth, what Latour defines as "terrestrials" or the earthbound' (Derme, Mitterberger 2020). The term 'earthbound people' was a theoretical idea proposed by Bruno Latour during his 2013 Gifford Lectures, Facing Gaia: Six Lectures on the Political Theology of Nature and in Facing Gaia: Eight Lectures on the New Climatic Regime (2017); the term was used by the Institute for Earthbound Studies. ${ }^{29}$

For the installation, they produced 3D-printed artificial flowers using the discovered patterns of reflections. They also used synthetic pollen to fill the flower with food for the bat. ${ }^{30}$ The scientists/artists register the sound frequencies of the bats and translate them into visual information visible to the human eye.

Moreover, while the first exhibition mentioned above scientifically documented echolocation, the aforementioned science and art piece on interspecies communication transferred echolocation into the visual, auditory and tactual segment that is inherent to human communication and thereby segmented its research to a single bat species - the nectar-feeding bats, who have a unique system of sensory compensation that allows them to forage in cluttered spaces such as rain forests, so as to find the tiniest of flowers. ${ }^{31}$ The artists thereby highlighted the role of the aforementioned art and science project within the context of biosonar technology: 'Biosonar technologies are found in nature in mainly two groups of animals: bats and moths use aerial biosonar, whereas whales and dolphins use aquatic biosonar'. Alongside the biosonar technology matrix, the aforementioned artists also stress the role of sensory ecology (Derme, Mitterberger 2020), which studies the manner in which organisms acquire and respond to information about their environment, and cite as an example the sensory system of the bats' echolocation.

Furthermore, while the aforementioned artists point out that ' $[\mathrm{t}]$ he field of empathy and emotion does not really have space within the realm of science, very much in the sense of "what you cannot name, cannot exist"” (Derme, Mitterberger 2020), I would like to note that in her book Estetika kibersvijeta $i$ ucinci derealizacije (Aesthetics of the Cyberworld and the Effects of De-Realisation), in the chapter on artificial life and terminal positioning, Marina Gržinić states that the highlight of mechanical simulation in the $18^{\text {th }}$ century was de Vaucanson's mechanical duck 'that drank, ate, quacked... and

\footnotetext{
${ }^{29}$ Cf. https://www.earthboundpeople.com/earthbound-people/

${ }^{30}$ For more details on the project, cf. http://emare.eu/artist/maeid-\%E2\%80\%93-tizian-derme-daniela-mitterberger

${ }^{31}$ I use the pronoun who instead of which/that so as to avoid speciesist language, along the lines of Joan Dunayer's book on speciesism.
} 
digested food just like a living duck'. The aforementioned production of artificial life comprises an introduction into the author's deliberation on artistic strategies of genetic engineering, within which Oron Catts, Ionat Zurr and Guy Ben-Ary (The Tissue Culture \& Art Project) cultivate living fibrous microorganisms as living sculptures; the author thereby conveys a bioethical query-suspicion: 'We must ask ourselves, however, as to what happens with a living sculpture once its value on the art market decreases'. Even though they are primarily scientists, on their webpage Daniela Mitterberger and Tiziano Derme also underline the artistic matrix of their research - 'media artists and architects Daniela Mitterberger and Tiziano Derme are the co-founders and directors of MAEID / Büro für Architektur und transmediale Kunst, an interdisciplinary design studio created to locate critically new technologies within novel human-animal-machine entanglements.' ${ }^{32}$

In terms of context, I would also like to mention the first ethnozoological exhibition in Croatia, which also accentuated the animal rights matrix - Of Animals and Humans (O životinjama i ljudima, Zagreb, Ethnographic Museum, 22 April - 12 November 2017, curators: Željka Petrović Osmak, Tea Rittig Šiško, Gordana Viljetić), for the catalogue of which curator Aida Brenko wrote on multispecies ethnography, presented some years earlier by anthropologists Eben Kirksey and Stefan Helmreich, who in turn agree with anthropologist Eduard Kohn's statement that that multispecies ethnography acknowledges the interconnectedness and inseparability of humans and other life forms, and thus seeks to extend ethnography beyond the solely human realm and anthropocentrism (cf. Kirksey, Helmreich 2010: 562-563, Brenko 2017: 180). The author also notes the project The Multispecies Salon (ed. Eben Kirksey, Duke University Press Books, 2014), in which plants, animals, fungi, microbes and viruses write natural and cultural history together with humans. Briefly put, The Multispecies Salon is a project in which anthropologists collaborate with artists and biologists, thus demonstrating how the lives of different organisms intertwine in political, economic and cultural contexts, implementing new approaches to the ways of being and 'becoming' in the world (ibid.). As opposed to the human-animal studies or traditional animal studies, the emphasis is placed on the fact that multispecies ethnography expands its research (as underlined above) to fungi, microbes, viruses and the plant world, and also fosters cooperation with ecoart and bioart (Kirksey, Schuetze, Helmreich 2014: 2). Here we should point out the intrinsic value of bats. Not only their benefit for people (e.g., eating mosquitoes, pollination, etc.) but rather the worth of bats for themselves. In the aforementioned context, the project The Eye of the Other can be defined as an example of an 'interspecies salon', even though the artists themselves do not refer to the aforementioned project.

Finally, I find the link between the two aforementioned exhibitions - the scientific one, Technologies in Biology: Bats, and the science and art exhibition project The Eye of the Other (even though emphasis is placed on the scientific segment - since the authors point out two scientific niches (i.e., biosonar technologies and sensory ecology)) in their application of animal communication to the scientific sphere, hence, in the anthropological dimension. While the first exhibition accentuated the manner in which echolocation and flight of bats were applied to certain scientific discoveries (e.g., Leonardo's research

\footnotetext{
${ }^{32} \mathrm{Cf}$. http://emare.eu/artist/maeid-\%E2\%80\%93-tizian-derme-daniela-mitterberger
} 
of bat flight and its application to human flight, the application of echolocation to the inventions of radar and sonar), the exhibition The Eye of the Other equally applies the aforementioned bat-experiences to contemporary scientific discoveries. The installation The Eye of the Other uses bat behaviour and their echo-sounding influence research into technologies such as self-driving cars.

\begin{abstract}
Bats, by themselves, are considered a top-level order within mammals, due to their highly ecological and evolutionary success. Specifically, the study of their biosonar system is currently making crucial advancement for technologies applied to radar and computer vision devices. These applications use sonar to facilitate and interpret representations of three-dimensional geometry in the output signal (computer vision). Self-driving cars are currently using sonar technologies to manoeuvre the vehicles in the event of fog detection and low visibility situations. Furthermore, since the sound propagates across different media, the use of sonar is still the best technology for interpreting special environmental circumstances (Derme, Mitterberger 2020).
\end{abstract}

Finally, I would like to note a series of smaller-scale popular science exhibitions intended for children, which took place in several cities in Croatia to mark the International Bat Night. For example, Osijek marked the $9^{\text {th }}$ Bat Night (29-30 August) in 2020 at the $Z_{0 o}^{33}$ under the programmatic motto 'Bats aren't to blame for the coronavirus, but could help Osijek get rid of mosquitos' as an appeal to revoke the demonisation of bats, which culminated in 2020 due to the alleged correlation between the demonised Chinese bat and the pandemic. The demonisation of the aforementioned only flying mammal began in 2003, when SARS killed approximately 800 persons due to the virus that probably originated from a bat species found in a Yunnan cave. ${ }^{34}$ Another story, however, connects SARS with this 2020 pandemic, and may have come from Professor Shi Zhengli from the Wuhan Institute of Virology (WIV), also known as the Bat Woman, who gained international recognition for her discovery of SARS.

Suzana Marjanić

\footnotetext{
${ }_{33}$ As speciesist places for animals, zoos often serve today as spaces at which popular and expert programmes for children are held, which is one of the signs of contemporary schizophrenia of our attitude towards animals. Furthermore, the art project The Eye of the Other did not conduct an on-site research in the habitat of the nectar-feeding bats, but rather 'only in the captive environment of the Vienna Zoo - one of the few places in Europe where it is currently possible to observe a colony of nectar-feeding bats. Doing fieldwork allowed us to realise the relational fragility of working with animals.' The project was thereby not conceived within the framework of the zoo-ethical niche, since - as the artists stress further in the interview - 'The fear of animal rights groups surrounded the project, not necessarily aimed at us, but it was here whenever we were interested in collaborating with research facilities' (Derme, Mitterberger 2020).

34 Index Vijesti: 'Znanstvenicu iz Wuhana optužuju za širenje korone iz laboratorija, sad je progovorila.' https:// www.index.hr/vijesti/clanak/znanstvenicu-iz-wuhana-optuzuju-za-sirenje-korone-iz-laboratorija-sad-je-progovorila/2241084.aspx; Qui, Jane: 'How China's “Bat Woman” Hunted Down Viruses from SARS to the New Coronavirus,,'”ttps://www.scientificamerican.com/article/how-chinas-bat-woman-hunted-down-viruses-fromsars-to-the-new-coronavirus1/
} 


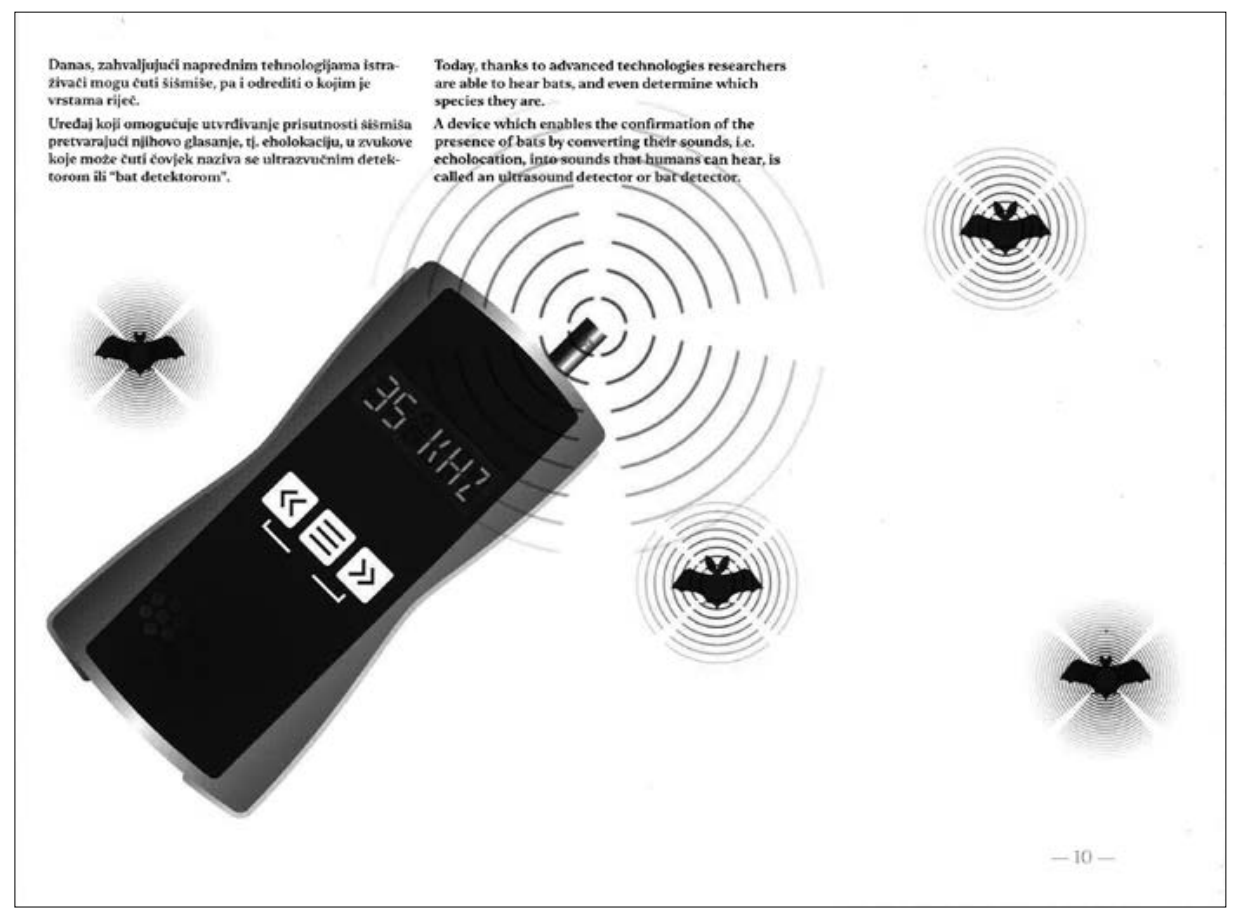

Fig. 8. Bat Detector; from the exhibition catalogue Technologies in Biology: Bats (Tehnologije u biologiji: Šišmiši, Zagreb, Nikola Tesla Technical Museum, 2019).

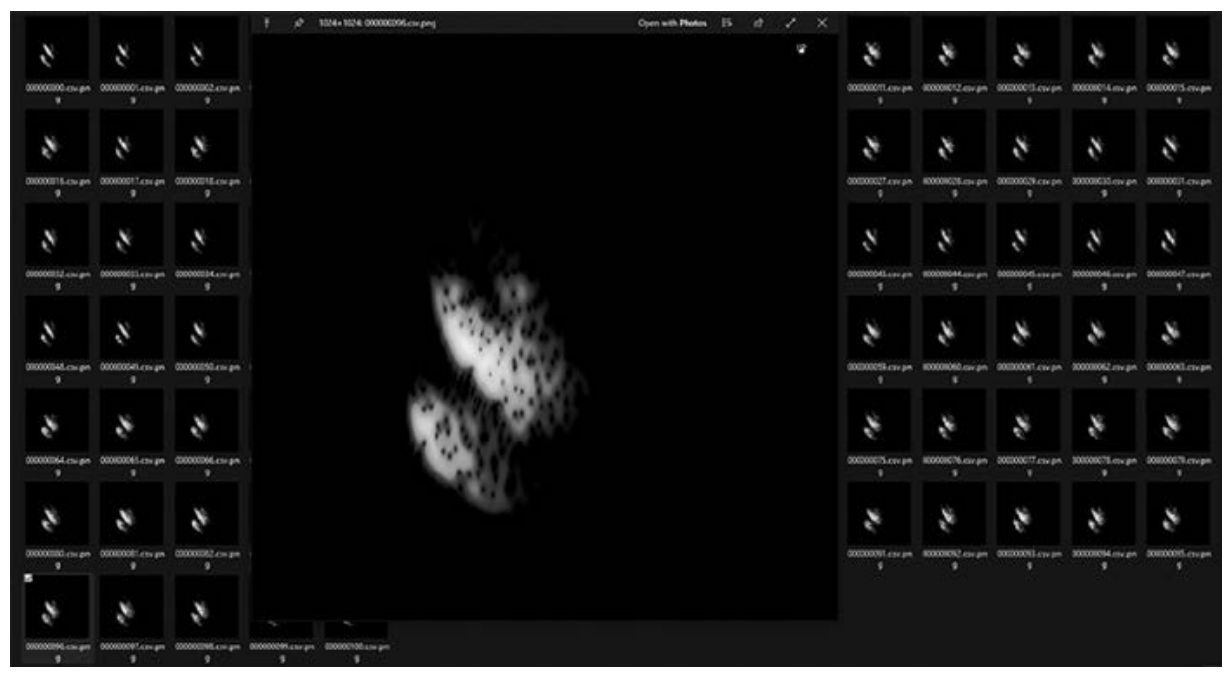

Fig. 9. The Eye of the Other - Flower echo patterns database generation using machine learning algorithms, 2019 (C) MAEID. Taken from the website of this art and science project (source: https:// www.makery.info/en/2020/11/18/la-chauve-souris-que-donc-je-suis-the-eye-of-the-other-de-danielamitterberger-tiziano-derme/). 


\section{TO CONCLUDE: BATS DO NOT SPREAD COVID-19*}

To also conclude along the lines of the book Invitation to Terror: The Expanding Empire of the Unknown (2007) by sociologist Frank Furedi: the states that the dangers ahead of us (i.e., terrorism, global warming and viral epidemics) are increasingly interpreted and perceived as threats that are much worse than we could ever imagine - 'They are also represented as threats of which we, in fact, know very little, and we are in no position to know very much thereof' (Furedi 2009: 104, emphasis added). Or, as sensibly stated by Didier Raoult, a microbiologist specialised in infectious diseases and Head of the University Hospital Institute for Infectious Diseases in Marseille, the largest of its kind in France (anthrax, chikungunya, Ebola, bird flu, H1N1, Zika, coronaviruses SARS and MERS $^{35}$ ) all of these epidemics were expected to cause a million deaths, but none of them occurred to a pandemic extent. The media are very well aware of the fact that the manipulation of fear sells newspapers and increases viewing ratings, and when they (now powered by the $5 \mathrm{G}$ network, introduced during the very pandemic lockdown) are joined by politicians, what we have is a well-known convergence of large-scale capital and politics, which generates wars, in this case, biological ones. Here we can refer to Rüdiger Safranski, who indicated that globality has ceased to be the concept of unspeakable expanses and became a prison and site of hysteria and the inability to act.

Or, as Ludwig Wittgenstein stated in his 1921 book Tractatus Logico-Philosophicus: 'From current events we cannot conclude what the events will be in the future'.

\section{Translated by Marta Ptičar, Mirta Jurilj and Goran Đurđević.}

\section{BIBLIOGRAPHY}

Aesop (author), George Fyler Townsend (translator), 2007: Aesop's Fables. College Town: Pennsylvania State University.

Alighieri, Dante (author), Henry Wadsworth Longfellow (translator), 2007: Divine Comedy, Longfellow's Translation, Hell. Ebook Gutenberg project. Internet: https://www.gutenberg.org/ files/1001/1001-h/1001-h.htm\#CantoXXXIV (12. 10. 2020).

Amirthalingam, 2005: Sacred animals of Tamilnadu. In: Krishna, Nanditha (ed.), Ecological traditions of Tamilnadu. Chennai: C.P.R. Environmental Education Centre, 126-135.

Andrews, Travis, 2019: Ozzy Osbourne bit the head off a bat 37 years ago, and, for some reason, now a toy commemorates it. Washington Post, January 23, 2019.

\footnotetext{
${ }^{35}$ Didier Raoult thus states that 'if we compare the millions of people who die worldwide with those who have died of conditions such as cow madness, bird flu no. 1, bird flu no. 2, the H1N1 flu, MERS, SARS, Ebola, chikungunya or Zika, i.e., if we consider the small number of deaths from these infectious diseases in relation to the large number of people who died of other causes, we will be taken aback' (Raoult 2020: 100).

* The text is a variant of the presentation at the scientific conference "Covid-19 in a humanistic perspective: mutations of fear and cultural change" organized by Institute of Ethnology and Folklore Research in Zagreb, $28-30$ September 2020. The first, shorter and quite different version of text has been published on interactive website Political Lexicon of Pandemics edited by Zlatko Bukač, Biljana Kašić, Jelena Kupsjak, Atila Lukić and Gordan Maslov from Centre for Research in Social Sciences and Humanities in Zadar.
} 
Armstrong, Philip, Simmons, Laurence, 2007: Bestiary: an introduction. In Simmons, Laurence, Armstrong, Philip (eds.), Knowing Animals. Leiden: Brill, 1-26.

Barnes, Shawn S., Hunt, Terry L., 2005: Samoa's Pre-contact Connections in West Polynesia and Beyond. The Journal of the Polynesian Society, 114/3, 227-266.

Bats in Greco-Roman Antiquity. Bats magazine, 29/2, Internet: https://www.batcon.org/article/ bats-in-greco-roman-antiquity/ (25. 11. 2020).

Benson, Elizabeth P, 1987: Bats in South American Iconography. Andean Past 1, 165-190.

Benson, Elizabeth P.: Bats have fascinated people for thousands of years - especially in the New World tropics where more kinds of bats live than anywhere else in the world... Bats magazine, 9/1. Internet: https://www.batcon.org/article/bats-in-south-american-folkloreand-ancient-art/ (10.11.2020).

Brenko, Aida. 2017: Religije i životinje. In: Željka Petrović Osmak (ed.), O životinjama i ljudima. Zagreb: Etnografski muzej, 165-216.

Calisher, Charles H, 2006: Recent Recognition of Bats as Reservoir Hosts of Emerging Viruses. Infektološki glasnik, Croatian Journal of Infection, 26/5, 149-155.

Camazotz. Internet: English Wikipedia https://en.wikipedia.org/wiki/Camazotz (12. 9. 2020).

Cohen, Jon, 2020: Wuhan seafood market may not be source of novel virus spreading globally. Internet: https://www.sciencemag.org/news/2020/01/wuhan-seafood-market-may-not-besource-novel-virus-spreading-globally (29. 10. 2020).

Chevalier, Jean, Gheerbrant, Alain, 1983: Rječnik simbola. Mitovi, sni, običaji, geste, oblici, likovi, boje, brojevi. Zagreb: Nakladni zavod MH.

Coetzee, John Maxwell, 2004: Život životinjâ. Zagreb: AGM.

Cooper, Jean Campbell. 1986: Ilustrovana enciklopedija tradicionalnih simbola. Beograd: Prosveta - Nolit.

Derme, Tiziano, Mitterberger, Daniela, 2020: The Bat That Therefore I Am - Exploring the Eye of the Other. Interviewed by Rob La Frenais. Internet: https://www.makery.info/en/2020/11/18/ la-chauve-souris-que-donc-je-suis-the-eye-of-the-other-de-daniela-mitterberger-tizianoderme/ (29. 10. 2020)

Fenton, M. Brock, Ratcliffe, John M., 2010: Bats. Current Biology, 20/24, 1060-1062.

Furedi, Frank. 2009: Poziv na teror: rastuće carstvo nepoznatog. Zagreb: Naklada Ljevak.

Gellatley, Juliet, 2001: Kako postati, biti i ostati vegetarijanac ili vegan? Zagreb: Udruga Prijatelji životinja.

Grenoble, 2020. The Land Down Under seen through the eyes of Bunna, a native Australian. Internet: https://anglais-pedagogie.web.ac-grenoble.fr/sites/anglais-pedagogie.web.ac-grenoble. fr/files/the_land_down_under.pdf (30.11.2020).

Gura, Aleksandar, 2001: Slepi miš. In: Tolstoj, Svetlana, Radenković, Ljubinko (eds.), Slovenska mitologija - enciklopedijski rečnik. Beograd: Zepter Book World, 497-498.

Hayes, Polly, 2020: Here's how scientists know the coronavirus came from bats and wasn't made in a lab. The Conversation Internet: https://theconversation.com/heres-how-scientistsknow-the-coronavirus-came-from-bats-and-wasnt-made-in-a-lab-141850 (29. 10. 2020).

Hrvatska agencija za okoliš i prirodu. Šišmiši. Internet: http://www.haop.hr/hr/tematska-podrucja/ prirodne-vrijednosti-stanje-i-ocuvanje/bioraznolikost/sismisi (5. 11. 2020).

Ivanišin-Kardum, Katarina, Crnčević, Marija, Hamidović, Daniela, Henry Schofield and the Vincent Wildlife Trust, Rnjak, Dina, 2019: Technologies in Biology: Bats (Tehnologije u biologiji: Šišmiši). Zagreb: Technical Museum Nikola Tesla. 
Ji Xianlin, 1997: New Interpretation of the Unity of Heaven and Man. In: Ji Xianlin and Zhang Guanglin (eds.), Essays on Eastern and Western Cultures, 2 vols. Beijing: Economics Daily Press.

Jung, Carl Gustav, 1938: Psychology and Religion. In Psychology and Religion: West and East, Collected Works of C.G. Jung. New Haven: Yale University Press.

Kiatpattananon, Suppasit, 2017: Defense Mechanisms of Batman or Bruce Wayne in Christopher Nolan's "The Dark Knight Trilogy". Thesis, Chiang Mai University.

Kirksey, Eben, Craig Schuetze and Stefan Helmreich, 2014: Tactics of Multispecies Ethnography. In: Eben, Kirksey (ed.), Multispecies Salon. Durham, London: Dunke University Press, 1-24.

Kunz, Thomas, 1984: Halloween Treat: Bat Facts and Folklore. The American Biology Teacher, 46/7, 394-399.

Laird, Tessa, 2018: Bat. London: Reaktion Books.

Leutogi. English Wikipedia. Internet: https://en.wikipedia.org/wiki/Leutogi (3. 11. 2020).

Lévi-Strauss, Claude, 1964: Totemism. Boston: Beacon Press.

Linzey, Andrew, 1994: Animal Theology. Urbana and Chicago: University of Illinois Press.

Mageo, Jeanette, 2002: Myth, Cultural Identity, and Ethnopolitics: Samoa and the Tongan "Empire". Journal of Anthropological Research 58/4, 493-520.

Marimuthu, Ganapathy: A few privileged colonies of flying foxes are protected by time-honored tradition. Bats magazine, 6/2. Internet: https://www.batcon.org/article/the-sacred-flyingfox-of-india/ (10. 10. 2020).

Marjanić, Suzana: 2017: The Anthropology of Animals - Paradox and/or Necessity. In: Golež Kaučič, Marjetka (ed.), What to Do with Folklore? New Perspectives on Folklore Research. Wissenschaftlicher Verlag Trier, BASIS, Volume 9, 123-139.

Matchett, George and Davey, Graham C. L., 1991: A test of a disease-avoidance model of animal phobias. Behaviour Research and Therapy, 29, 91-94.

Mayen, Friederike, 2003: Haematophagous bats in Brazil, their role in rabies transmission, impact on public health, livestock industry and alternatives to an indiscriminate reduction of bat population. Journal of Veterinary Medicine, Ser. B-Infectious Diseases and Veterinary Public Health, 50, 469-472.

McCraken, Gary F.: The multiple uses of bats in magic and folk medicine are clear testament to the fertility of the human imagination... Bats magazine, 10/3. Internet: https://www.batcon. org/article/bats-in-magic-potions-and-medicinal-preparations/ (20. 10. 2020).

McCraken, Gary F.: Folklore about bats in buildings most often portends doom - a reflection, perhaps, on the way many cultures have viewed bats through the centuries... Bats magazine, 10/4. Internet: https://www.batcon.org/article/bats-in-belfries-and-other-places/ (20. 10. 2020).

McCraken, Gary F.: Throughout the world, folklore is rich with tales speculating on how creatures as mysterious as bats came to be ... Bats magazine, 11/4. Internet: https://www.batcon. org/article/folklore-and-the-origin-of-bats/ (26. 10. 2020).

Miller, Jill Flaningam, 2016: Animal Geography and Wildife Interpretation of Urban Bats. MA thesis, San Francisco State University.

Miller, Mary, Taube, Karl, 1997: An Illustrated Dictionary of the Gods and Symbols of Ancient Mexico and the Maya. London: Thames Hudson.

Moore, Kevin C. 2020: Readapting Pandemic Premediation and Propaganda: Soderbergh's Contagion amid COVID-19 (Program in Writing and Rhetoric, Stanford University, 590 Escondido Mall, Stanford, CA 94305-3069, USA; kcmoore@stanford.edu).“www.mdpi. com (18. 10. 2020). 
Morecroft, Richard, 1991: Raising Archie: The Story of Richard Morecroft and his Flying Fox. East Roseville, NSW: Simon\&Schuster.

Mulhall, Stephen, 2008: The Wounded Animal: J.M. Coetzee \& the Difficulty of Reality in Literature and Philosophy. Princeton: Princeton University Press.

Nagy, Kelsi, Johnson II, Phillip David, 2013: Introduction. In: Nagy, Kelsi, Johnson II, Phillip David (eds.), Trash Animals - how we live with nature's Filthy, feral, invasive, and unwanted species. Minneapolis: University of Minnesota Press, 1-30.

Netopiri, 2020: Hrvatska enciklopedija, mrežno izdanje. Leksikografski zavod Miroslav Krleža. Internet: http://www.enciklopedija.hr/Natuknica.aspx?ID=43510 (23. 10. 2020).

O'Neill, Marnie, 2020: Chinese influencer Wang Mengyun, aka 'Bat soup girl' breaks silence. Internet: https://www.news.com.au/lifestyle/food/food-warnings/chinese-influencer-wangmengyun-aka-bat-soup-girl-breaks-silence/news-story/63ef0cec5b6d448d1843e2e1bcadb14d (17. 10. 2020).

Nunez, Kirtsen. 2020: What's 'Bat Soup,' and Did It Cause the New Coronavirus? Healthline, Internet: https://www.healthline.com/health/bat-soup-coronavirus (6. 11. 2020).

Osaka, Keiko: Bat myths in Japan. Bats magazine, 34/4. Internet: https://www.batcon.org/article/ bat-myths-of-japan/ (10. 11. 2020.)

Osbourne, Ozzy, 2010: I am Ozzy. New York: Grand Central Publishing.

Ovid, 1958: Metamorphoses, rev. ed. F. J. Miller (ed.), Loeb Classical Library, Cambridge, MA: Harvard University Press. Internet: https://www.theoi.com/Text/OvidMetamorphoses 1. html (3. 11. 2020).

Perić, Boris, Tomislav Pletenac. 2015: Zemlja iza šume. Vampirski mit u književnosti i na filmu. Zagreb: TIM press.

Petrović, Petar Ž. 1970: Slepi miš. In: Kulišić, Špiro, Petrović, Petar Ž., Pantelić, Nikola (eds.), Srpski mitološki rečnik. Beograd: Nolit, 268.

Plato, 1969: Plato in Twelve Volumes, Vols. 5 \& 6. Translated by Shorey, Paul. Cambridge, MA/ London: Harvard University Press; William Heinemann Ltd. Internet: http://www.perseus. tufts.edu/hopper/text?doc=urn:cts:greekLit:tlg0059.tlg030.perseus-eng1:5.479 (11. 11. 2020).

Pliny the Elder, 1855: The Natural History. Bostock, John (ed.). London: Taylor and Francis. Internet: http://www.perseus.tufts.edu/hopper/text?doc=Perseus\%3Atext\%3A1999.02.0137\%3Abook\%3D33\%3Achapter\%3D45 (7. 11. 2020).

Plumwood, Val, 1993: Feminism and the Mastery of Nature. London: Routledge.

Prokop, Pavol, Frančovičova, Jana and Kubiatko, Milan, 2009: Vampires are still alive: Slovakian students' attitudes towards bats. Anthropozos, 22/1, 19-30.

Pusztai, A. S. Bardocz, 2011: Potential Health Effects of Foods Derived from Genetically Modified Plants What are the Issues? Third World Network.

Raoult, Didier, 2020: Epidemije: stvarna opasnost i lažne uzbune. Od ptičje gripe do bolesti COVID-19. Zagreb.

Read, Kay Almere, González, Jason, 2000: Handbook of Mesoamerican Mythology. Santa Barbara, CA: ABC Clio.

Renfro, Stan: Several North American Indian tribes include bats in their traditional folklore. For the Navajo, the bat holds a special significance. Bats magazine, 6/1. Internet: https://www. batcon.org/article/the-bat-in-navajo-lore/ (8. 10. 2020).

Riccucci, Marco, 2011: Same-sex behavior in bats. Hystrix It. J. Mamm. (n.s.) 22/1, 139-147. 
Riccucci, Marco, 2012: Bats as materia medica: an ethnomedical review and implications for conservation. Vespertilio, 16, 249-270.

Safranski, Rüdiger. 2008: Koliko globalizacije čovjek može podnijeti? Zagreb: Naklada Ljevak.

Sax, Boria, 2001: The Mythical Zoo: An Encyclopedia of Animals in World Myth, Legend and Literature. Santa Barbara, CA: ABC Clio.

Schild, Leonard, Chen Ling, Jeremy Blackburn, Gianluca Stringhini, Yang Zhang, Savvas Zannettou, 2020. "Go eat a bat, Chang!": An Early Look on the Emergence of Sinophobic Behavior on Web Communities in the Face of COVID-19. Internet: https://www.researchgate.net/ publication/340523411_Go_eat_a_bat_Chang_An_Early_Look_on_the_Emergence_of_Sinophobic_Behavior_on_Web_Communities_in_the_Face_of_COVID-19 (27.9.2020).

Sumić Miletić, Tea, 2020: Ako smo koronavirus dobili od šišmiša, stanje bi uskoro moglo biti puno gore: uništavanjem šuma životinje stižu među ljude, a s njima i virusi. Slobodna Dalmacija, 27. ožujka 2020. Internet: https://slobodnadalmacija.hr/vijesti/svijet/ako-smo-koronavirus-dobili-od-sismisa-stanje-bi-uskoro-moglo-biti-puno-gore-unistavanjem-suma-zivotinje-stizu-medu-ljude-a-s-njima-i-virusi-1012250 (27. 9. 2020).

Svendsen, Lars Fr. H., 2019: Razumijemo li životinje?Filozofski pristup. Zagreb: TIM press.

Tuttle, Merlin D., 2017: Give Bats a Break. Issues in Science and Technology 33/3, 41-50.

Tvrtković, Nikola, 2017: Šišmiši Hrvatske: kratka povijest istraživanja i priručnik za određivanje $=$ Short Research History and Identification Key = Bats of Croatia . Rijeka/Zagreb: Prirodoslovni muzej Rijeka; Hrvatski prirodoslovni muzej.

Vičar, Branislava, 2013: “Si kdaj videl svobodnega konja?” Filozofski kontekst

animalistične etike v poeziji Jureta Detele in Miklavža Komelja. In: Bjelčević, Aleksander (ed.), Etika v slovenskem jeziku, literaturi in kulturi: zbornik predavanj / 49. seminar slovenskega jezika, literature in kulture, Ljubljana, 1. julij - 12. julij 2013. Ljubljana: Znanstvena založba Filozofske fakultete, 35-45.

Visković, Nikola, 1996: Životinja i čovjek: prilog kulturnoj zoologiji. Split: Književni krug Split.

Voon, Claire, 2017: Why Chinese Art Is Swarming with Colonies of Tiny Bats. Internet: https:// hyperallergic.com/406164/why-chinese-art-is-swarming-with-colonies-of-tiny-bats/ (29. 9. 2020).

Whitaker, John O. and Douglas, Louis R, 2006: Bat Rabies in Indiana. Journal of Wildlife Management, 70, 1569-1573.

Zaradija Kiš, Antonija, Marinka Šimić. 2020. Cvijet kreposti ili o naravi ljudskoj kroz narav životinjsku Zagreb: Institut za etnologiju i folkloristiku, Hrvatska sveučilišna naklada.

Zhang, Yunpeng, and Fang Xu, 2020: Ignorance, Orientalism and Sinophobia in Knowledge Production on COVID-19. Tijdschrift voor economische en sociale geografie 111/3, 211-223.

Žagar-Petrović, Mirjana, 2020: Covid-19 - nova bolest i novi virus koji su promijenili svijet. Internet: https://www.zdravobudi.hr/clanak/1770/novi-koronavirus-sars-cov-2-i-bolestcovid-19 (4. 10. 2020). 


\section{KAKO JE TO BITI ŠIŠMIŠ U DOBA COVIDA-19? ILI KOLIKO PANDEMIJE MOŽEMO PODNIJETI}

\section{Goran ĐurĐević, Suzana Marjanić}

$\bowtie$

Ovih je blizanačkih godina (2020-2021) kompletan svijet zapao u globalnu pandemiju Covid-19 koja je dovela do razvijanja različitih pretpostavki, neutemeljenih vijesti, post-istina i lažnih vijesti. Među takvima su prednjačile vijesti o šišmišu kao krivcu za širenje ovog virusa te posredno kineskoj prehrani kao uzroku svega. Iako još nije dokazana poveznica unutar trokuta šišmiš - virus - čovjek niti je određen nulti zaraženi (osim u Wuhanu, postoje indicije o ranijim zaraženima $u$ Italiji i SAD-u) kao ni izvor zaraze (osim šišmiša, ovi se virusi javljaju kod drugih životinja kao što su deve, ljuskavci i ljudi, pa, primjerice, neki znanstvenici obrću situaciju i pokazuju mogućnost prijenosa s čovjeka na životinju), bilo je posve „prihvatljivo“ demonizirati šišmiša. U ovom kontekstu autori podsjećaju na određene povijesne kontekste predodžbi i doživljaja šišmiša te sličnostima i razlikama unutar pandemije, posebno se osvrćući na hrvatski i globalni kontekst.

Završno, u kontekstu knjige Koliko globalizacije možemo podnijeti? R. Safranskog i u kontekstu demoniziranoga kineskoga šišmiša koji se u doba pandemije Covid-19 pojavljivao na brojnim internetskim portalima kao zoo-simbol digitalnoga folklora o kineskoj juhi, podsjetit ćemo na Nagelovo predavanje koji u svom utjecajnom članku „Kako je to biti šišmiš““ ( "What is It Like to Be a Bat”, 1974) pogađa u suštinu problema, a to je pitanje svijesti (qualia). Naime, koliko god istraživali, čak i imajući sve informacije o arhitekturi šišmiševog moždanog sklopa, ne možemo znati kakvo je njegovo iskustvo u doba pandemije.

U konačnici, autori zaključuju kako je priča o šišmišima zapravo izvrstan pokazatelj reprezentacija Drugosti i jačanja binarne i hijerarhizirane podjele „mi“ i ,oni“6.

Goran Đurđević, Ph.D., Beijing Foreign Studies University, goran.djurdjevich@ gmail.com

Suzana Marjanić, Ph.D., Institute of Ethnology and Folklore Research, Šubićeva ul. 42, HR-10000 Zagreb, suzana@ief.hr 